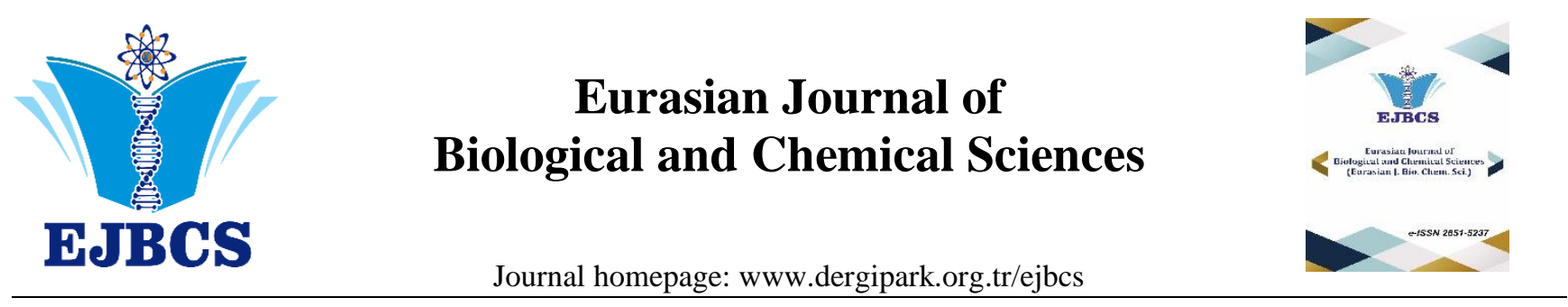

\title{
Anatomical Structure and Ecological of Cephalanthera damasonium (Mill.) Druce and Its on Contribution to the Taxonomy of Orchidaceae
}

\author{
Derviş ÖZTÜRK ${ }^{*}{ }^{*}$ \\ Eskişehir Osmangazi University, Mahmudiye Equine Vocational School, Department of Plant and Animal Production, Eskişehir, Turkey
}

*Corresponding author : dozturk @ogu.edu.tr

Orcid No: https://orcid.org/0000-0001-7189-7407

Received : 10/04/2020

Accepted : 01/04/2021

\begin{abstract}
In this study, in the present study reveals the morphological, anatomical and ecological characteristic of Cephalanthera damasonium (Mill.) Druce in Turkey. Plant materials of Cephalanthera species were collected from one population, between 2018 in Eskişehir/Turkey. C. damasonium (Mill.) Druce samples were analyzed for 7 anatomical and soil characters and habitat properties. It was investigated micrometrically in the anatomy of $C$. damasonium (Mill.) Druce. In morphological investigations, the structure of flower, lateral sepal, petal, dorsal sepal, lip, anther cap and column was determined. The findings were compared with those in Flora of Turkey. to habitat definition, C.damasonium (Mill.) Druce grew up to $800 \mathrm{~m}$ to $1200 \mathrm{~m}$.
\end{abstract}

Keywords: Anatomical, Morphological, Cephalanthera damasonium, Eskişehir, Turkey.

(C) EJBCS. All rights reserved.

\section{Introduction}

Orchidaceae is the most famous and attractive plant family among all plant families of the world. Turkey is a rich country of terrestrial orchids and represented by 150 taxa (Arditti, 1992; Prigdeon, 1992; Julou at al. 2005). Turkish orchidaceae were introduced in the volume 8 and 11 of Flora of Turkey. In Turkey, Orchidaceae is represented by 26 genus and about 166 species, of which 60 are endemic (Davis et al. 1978; Güner et al. 2000; Ataşlar, 2018; Dreesler, 1983; Pecoraro et al. 2017; Šegota et al. 2012; Stöckel et al. 2011). Terrestrial orchids have creeping, much reduced, fibrous or fleshy rhizomes or tuber like roots. Orchis L. taxa are terrestrial orchids and diagnosed by a basal rosette and terminal, unbranched infloresence that is composed of small to moderately large resupinate flowers. This genus belonged to the Orchidinae tribe of which 30 species demonstrate their main distribution in the Northern regions of Europe and Asia (Renz and Taubenheim, 1984; Dressler, 1993; Kreutz, 2000; Kreutz, 2009; Abadie et al. 2006; Dafni and Ivri 1981). Most cultivars are tropical or sub-tropical. This species is known as salep in Turkey likes many other members of Orchidaceae (Baytop, 1997; Akman et al. 2014).

Orchids are nearly found in all ecosystems around the world except for glaciers, true desert and open water, although tropical areas especially in Asia, Africa and America are the hot spots of diversity. Orchis is a major genus of Orchidaceae family in Flora of Turkey, represented by 22 species (Renz and Taubenheim, 1984; Kreutz, 2000). In the last description study on Orchis (Kreutz, 2009), some species were classified under the genus Anacamptis and Neotinea (Kreutz, 2009). In this study, the nomenclature of Orchis is according to the Flora of Turkey (Renz and Taubenheim, 1984).

The charisma of orchids and their biology have attracted botanists and general public as many varieties and hybrids are widely cultivated; this passion has inspired intrepid collecting expeditions and spawned hundreds of orchid societies and clubs around the world, spawning a global cultivation industry worth nine-billion dollars annually (Ziegler, 2007; Çepel N. 1988). Ecology, morphology and anatomy of several Turkish Orchid species have been studied earlier (Durmuskahya, 2013; Durmuskahya et al., 2014; Aybeke et al., 2010). Turkey has a rich biodiversity and has got more than 170 taxa (Kreutz, 2009). In high of the above, the aim of the present study was to investigate new ecological, morphological and anatomical information about another orchis taxa and to provide base knowledge for further studies. This species is known as salep in 
Turkey likes many other members of Orchidaceae (Baytop, 1997; Tuzlaci, 2006).

The aim of the present study is to describe the morphological and anatomical structure and in addition to investigate the epidermal cell and stomata of leaves of Cephalanthera damasonium.

\section{Materials and Method}

C. damasonium was collected from Eskişehir: SarıcakayaHekimdağ, below Quercus trees, 1000 m., 19.05.2018 and stored in the Eskişehir Osmangazi University Herbarium as a herbarium specimen (OUFE 12509). Determination of the species was made according to the Davis (1978 \& 1988). Morphological descriptions are based on living plants and herbarium specimens.

Anatomical investigations were applied on the leaves of samples fixed in $70 \%$ alcohol. The transverse sections discarded from mid-vessels of leaves were stained with safranin and upper and lower surface layers were investigated in the media with 20\% gliserin (Vardar, 1987). The well-staining sections were photographed on Leica DFC 295 color camera type, Leica DM 2500 light microscope. In this study, total 5 plant samples were collected for anatomical studies.

The surface layer of soil was removed and soil samples taken from $0-5$ and $5-15 \mathrm{~cm}$ depth were analysed. The samples were air dried, ground, passed through a $2 \mathrm{~mm}$ sieve and subjected to physico-chemical analysis. Total soluble salts, $\mathrm{pH}$, calcium carbonate content and texture were determined by the methods outlined in detail by Ozturk et al. (1997).

\section{Results}

Plant $15-45 \mathrm{~cm}$. Basal leaves usually broadly lanceolate and unspotted. Spike ovoid to conical, withnflowers opening from top downwards. Flowers whitish pink, with an upswept hood; lip conspicuous and in shape of a man with body.

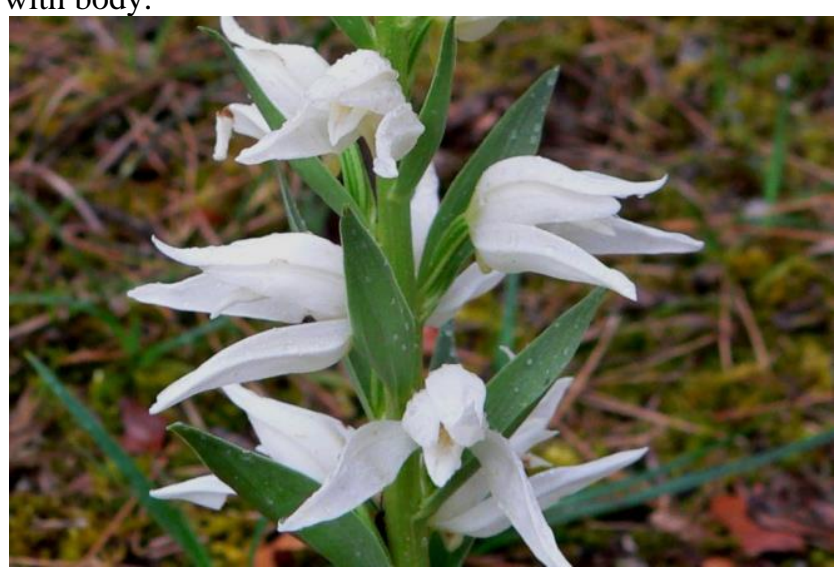

Fig. 1 C. damasonium (Mill.) Druce habitat view.

C. damasonium (Mill.) Druce is labellum $15-20 \mathrm{~mm}$, centre whitish-rose, deeply segmented near base into linear lateral lobes, middle lobe ligulate, divided into 2 linear lobules; all lobules darker purple towards apex. Spur cylindrical. Fl. 4-5. Grassy hillsides, Scrub, on calcerous soils, Quercus scrub, 900-1000 m. (P.H. Davis, 1978) (Fig 1).

Cross section of root showed single layered epidermal cells. The cell length was longer than width $(30-60 \times 45$ $100 \mu \mathrm{m})$. Cortex consisted of 7-12 layered parenchymatous cells. The shape of cortex cells ranged from oval to globular. These cells were 60-100 $\mu \mathrm{m}$ in diameter and their walls were thin. Parancymatic cells located far from center were smaller than the ones close to center (Fig. 1A). Similar results have been earlier reported by several authors in members of Orchidaceae family (Aykebe et al., 2010; Altundag et al., 2012; Durmuskahya et al., 2014). Endodermal cells $(35-50 \times 45-100 \mu \mathrm{m})$ with thickened wall were seen. Pericycle was single-layered and located under endodermis. (Fig. 2, Tab. 1).
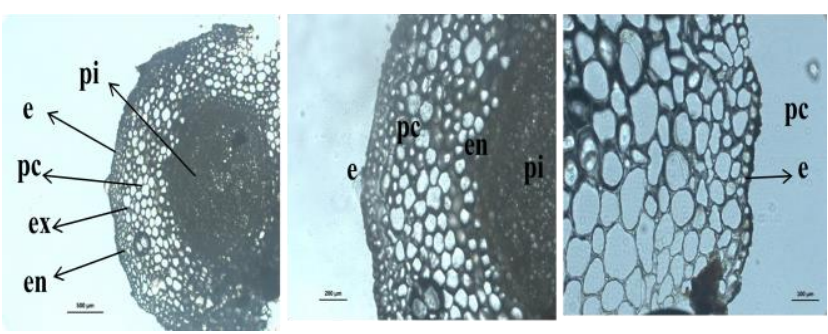

Fig. 2 Root transverse section of $C$. damasonium . e epidermis, ex exodermis, pc parenchymatic cells, en endodermis, ph phloem, xy xylem, pi pith (Bar $100 \mu \mathrm{m})$

\begin{tabular}{llllll}
\hline & \multicolumn{2}{l}{ Width $(\boldsymbol{\mu m})$} & & \multicolumn{2}{l}{ Length $(\boldsymbol{\mu m})$} \\
\cline { 2 - 3 } \cline { 5 - 5 } & Min. & Max. & & Min. & Max. \\
\hline Root & & & & \\
Epidermis & 15 & 25 & & 25 & 60 \\
Cortex & 40 & 120 & & 70 & 105 \\
parenchyma & & & & & \\
Endodermis & 10 & 35 & & 20 & 60
\end{tabular}

Table 1 Root anatomy measurement of $C$. damasonium (Figure 2)

The anatomical section of stem showed thick cuticle layer. Under this layer there was a single layered epidermis. Epidermal cells were square or rectangular shaped, 35-150 $\times 30-50 \mu \mathrm{m}$. 8-16 layers of cortex cells were found under epidermis with 20-30 $\mu \mathrm{m}$ diameter. Few collenchyma cells with thick and lignified cell walls were found in cortex layer. 10-24 layered collenchyma cells gave durability to the stem. (Fig. 3). Vascular bundles were collateral and located in one ring. The bundle sheath consisted of sclerenchymatic cells, at the phloem pole of vascular bundles. Pith had many lacunas in the centre of stem due to the breakup of pith into pieces (Fig. 3, Tab. 2). 

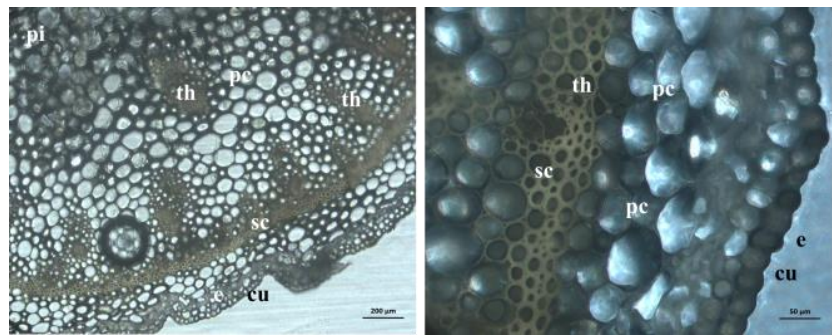

Fig. 3 Stem transverse section of $C$. damasonium (Mill.) Druce, cu cuticle, e epidermis, pc parenchymatic cells, th trachea, pi pith (Bar $100 \mu \mathrm{m})$

Table 2 Stem anatomy measurement of $C$. damasonium (Mill.) Druce . (Figure 3)

\begin{tabular}{llll}
\hline \multicolumn{2}{l}{ Width $(\mu \mathrm{m})$} & & \multicolumn{2}{l}{ Length $(\mu \mathrm{m})$} \\
& & & Min. Max. Max.
\end{tabular}

\section{Stem}

$\begin{array}{lllll}\text { Epidermis } & 20 & 40 & 30 & 50 \\ \text { Cortex } & 30 & 60 & 50 & 110 \\ \text { parenchyma } & & & & \\ \text { Trachea } & 125 & 240 & 200 & 350 \\ \text { (diameter) } & & & & \end{array}$

In leaves, adaxial epidermis consisted of a single layer of rectangular cells $25-80 \times 30-60 \mu \mathrm{m}$ with smooth cuticle. Abaxial epidermis was 55-80 $\times 35-50 \mu \mathrm{m}$. Adaxial epidermis cells were bigger than abaxial epidermis cells and adaxial cuticle thicker than adaxial. These features were observed in $O$. laxiflora Lam and $O$. purpurea Hudson by Aybeke et al. (2010). But Sevgi et al. (2012) observed that these species had thicker cuticle on abaxial side and they had similar thickness on both adaxial and abaxial surface. Mesophyll layer was homogenous, without any differentiation in to palisade and sponge parenchyma tissues (Fig. 4, Tab. 3).

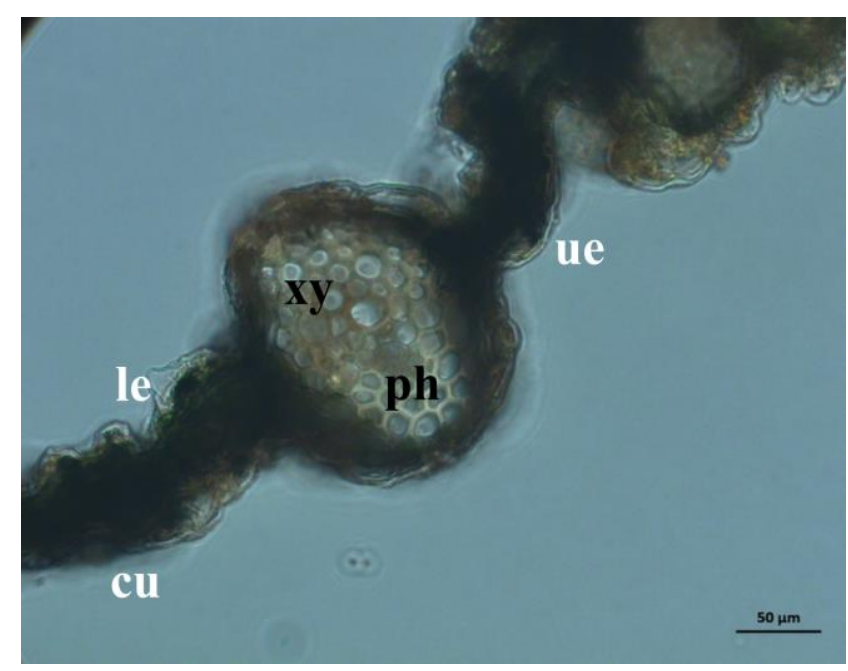

Fig. 4 Leaf transverse section of $C$. damasonium (Mill.) Druce, c cuticle, ue upper epidermis, $\mathrm{p}$ parenchyma, ph phloem, xy xylem, le lower epidermis (Bar $100 \mu \mathrm{m})$
Table 3 Leaf anatomy measurement of $C$. damasonium (Figure 4)

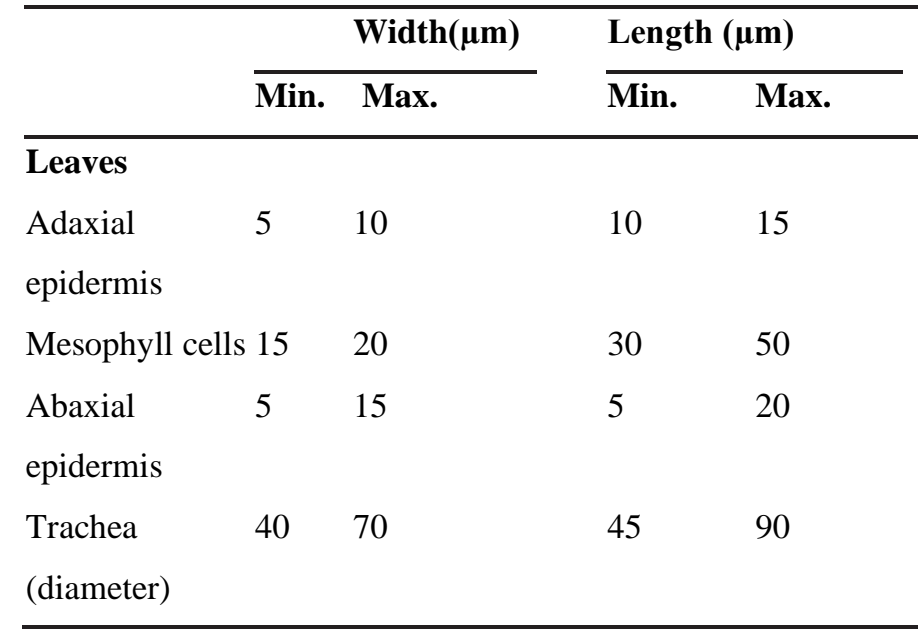

Leaves surface of investigated species was glabrous like many other orchid species. In leaves, adaxial epidermis consisted of a single layer of rectangular cells 50-110 $\times$ $80-85 \mu \mathrm{m}$ with smooth cuticle. Abaxial epidermis was 45 $100 \times 55-155 \mu \mathrm{m}$. Adaxial epidermis cells were bigger than abaxial epidermis cells and adaxial cuticle thicker than adaxial. (Fig. 5, Tab. 4).
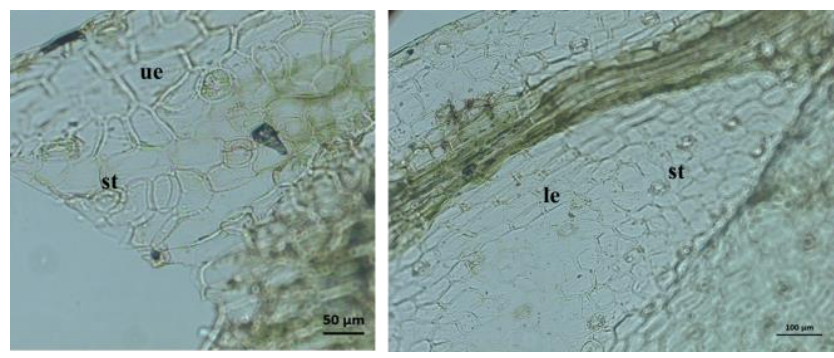

Fig. 5 Leaf epidermal peeling of $C$. damasonium (Mill.) Druce, ue upper epidermis, le lower epidermis, st stomata (Bar $100 \mu \mathrm{m})$

Table 4 Leaf anatomy measurement of $C$. damasonium (Figure 5)

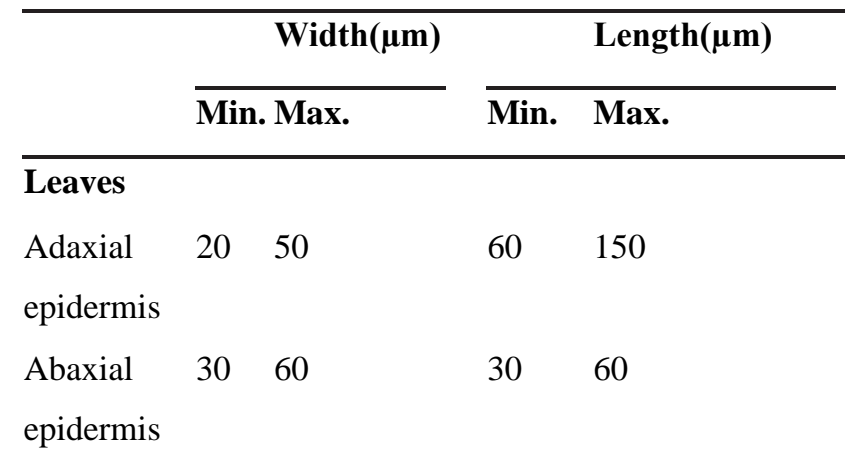

\section{Discussion}

In this study $C$. damasonium (Mill.) Druce was investigated ecology, morphologically and anatomically. Morphological drawings of flower, lateral sepal, dorsal sepal, petal, lip, anther cap and column were made. The results obtained from morphological studies were 
generally consistent with the description given in the Flora of Turkey (Davis 1978 \& 1988). As a whole this study increase the knowledge of the morphology and anatomy in Orchis reporting data about the C.damasonium (Mill.) Druce.

\section{Conclusion}

Cross section of root showed single layered epidermal cells. The cell length was longer than width $(15-25 \times 25$ $60 \mu \mathrm{m})$. Cortex consisted of 10-16 layered parenchymatous cells. The shape of cortex cells ranged from oval to globular. Parancymatic cells located far from center were smaller than the ones close to center (Fig. 2). Endodermal cells $(10-35 \times 20-60 \mu \mathrm{m})$ with thickened wall were seen clearly. Pericycle was single-layered and located under endodermis. (Fig. 2). The anatomical section of stem showed thick cuticle layer. Under this layer there was a single layered epidermis. Epidermal cells were square or rectangular shaped, 20-40 × 30- 50 $\mu \mathrm{m}$. 20-30 layers of cortex cells were found under epidermis with $40-80 \mu \mathrm{m}$ diameter. Few collenchyma cells with thick and lignified cell walls were found in cortex layer. Vascular bundles were collateral and located in one ring. The bundle sheath consisted of sclerenchymatic cells, at the phloem pole of vascular bundles. Pith had many lacunas in the centre of stem due to the breakup of pith into pieces (Fig. 3).

Leaves surface of investigated species was glabrous like many other orchidaceae species. In leaves, adaxial epidermis consisted of a single layer of rectangular cells $(5-10 \times 10-15 \mu \mathrm{m})$ with smooth cuticle. Abaxial epidermis was 5-15 $\times 5-20 \mu \mathrm{m}$. Adaxial epidermis cells were bigger than abaxial epidermis cells and adaxial cuticle thicker than adaxial. Mesophyll layer was homogenous, without any differentiation in to palisade and sponge parenchyma tissues (Fig. 4).

\section{References}

Abadie JC, Püttsepp Ü, Gebauer G, Faccio A, Bonfante P, \& Selosse MA. 2006. Cephalanthera longifolia (Neottieae, Orchidaceae) is mixotrophic: a comparative study between green and nonphotosynthetic individuals. Botany. 84(9): 1462-1477.

Akman Y, Ketenoğlu O, Kurt L, \& Vural M. 2014. The steppe vegetation of Inner Anatolia.

Altundag E, Sevgi E, Kara O, Sevgi O, Tecimen HB, Bolat I. (2012). Comparative morphological, anatomical and habitat studies on Dactylorhiza romana (Seb.) Soó subsp. romana and Dactylorhiza romana (Seb.) Soó subsp. georgica (Klinge) Soó ex Renz \& Taub.(Orchidaceae) in Turkey. Pak J Bot, 44, 143-152.

Arditti J. 1992. Fundamentals of orchid biology. John Wiley \& Sons.

Ataşlar E. 2018. Morpho-anatomical structure of Orchis mascula (L.) L. and its contribution to the taxonomy of Orchidaceae. EIJST. 7(6).

Aybeke M, Sezik E, Olgun G. 2010. Vegetative anatomy of some Ophrys, Orchis and Dactylorhiza (Orchidaceae) taxa in Trakya region of Turkey. Flora. 205(2): 73-89.

Baytop, T. Turkish Plant Name Dictionary, Atatürk Culture, Linguistic and History Association Publishing No: 578, p: 521, Ankara, (1997).
Dafni A, Ivri Y. 1981. The flower biology of Cephalanthera longifolia (Orchidaceae) pollen imitation and facultative floral mimicry. Plant Syst Evol. 137(4): 229-240.

Çepel N. 1988. Toprak İlmi Ders Kitabı; Orman Topraklarının Karakteristikleri, Toprakların Oluşumu, Özellikleri ve Ekolojik Bakımdan Değerlendirilmesi. İÜ Orman Fakültesi Yayınlar1, Yayın, (3416-389).

Davis PH. 1978. Flora of Turkey and The East Aegean Islands 8, Edinburgh Univ. Press, Edinburgh.

Davis, P. H., Mill, R. R. \& Tan, K. (Eds.) (1988). Flora of Turkey and the East Aegean Islands.Volume 10, 289. Edinburg University Press.

Dreesler RL. 1993. Phylogeny and classification of the orchid family. Dioscorides Press, p. 314.

Durmuşkahya, C.: Orchids of Mugla T.C. Forest and Water Ministry Publishing, Mugla,Turkey, p:60, (2013).

Durmuskahya, C., C. Ozdemir, B. Bozdag and M. Ozturk: Studies on the Morphology, Anatomy and Ecology of Ophrys lutea Cav. Subsp. Minor (Guss.) O. Danesch \& E. Danesch ex Golz \& H.R. Reinhard (Orchidaceae) in Turkey. Paki. J. Bot., 46, 81-88, (2014).

Güner A, Özhatay N, Ekim T, Başer KHC. 2000. Flora of Turkey and the east Aegean Islands. Supplement 2: 28.

Julou T, Burghardt B, Gebauer G, Berveiller D, Damesin C, Selosse MA. 2005. Mixotrophy in orchids: insights from a comparative study of green individuals and nonphotosynthetic individuals of Cephalanthera damasonium. New Phytologist, 166(2): 639-653.

Kreutz CAJ. 2000. Orchidaceae. In Flora of Turkey and the East Aegean islands (Eds.: A Guner, N Ozhatay, T Ekim, KHC Baser). Edinburg University Press, Edinburgh, 11: 274 - 303.

Kreutz CAJ. 2009. Orchids of Turkey, Botanical Properties, Ecological Requirements, Natural Spreading Sites, Vital Threats, Precautions for Protection (Trans \& Cont. A Colak), Rota Publications, pp 55-848.

Ozturk, M., M. Pirdal and F. Ozdemir. 1997. Applications in Plant Ecology. Ege University, Science Faculty Book Series No: 157, Ege Un, iversity Press, Đzmir, Tuırkey.

Pecoraro L, Huang L, Caruso T, Perotto S., Girlandam M, Cai L., \& Liu ZJ. 2017. Fungal diversity and specificity in Cephalanthera damasonium and C. longifolia (Orchidaceae) mycorrhizas. JSE. 55(2): 158-169.

Renz J, Taubenheim G. 1984. Dactylorhiza Necker ex Nevski. Flora of Turkey and the east Aegean islands, 8:535-551.

Renz J, and G Taubenheim. 1984. Orchis L. (Orchidaceae), In: Flora of Turkey and the East Aegean islands (Eds.: P.H. Davis). Edinburgh, University Press, Edinburgh. 8: 451-600.

Šegota V, Hršak V, Alegro A. 2012. Cephalanthera damasonium (Mill.) Druce in Mediterranean evergreen vegetation. Natura Croatica: Periodicum Musei Historiae Naturalis Croatici. 21(1): 247-254.

Sevgi E, Altundag E, Kara O, Sevgi O, Tecimen HB, Bolat I. 2012. Morphological, anatomical and ecological studies on some Orchis (Orchidaceae) taxa of Mediterranean region, Turkey. JEB. 33(2): 343.

Stöckel, M, Meyer C, Gebauer G. 2011. The degree of mycoheterotrophic carbon gain in green, variegated and vegetative albino individuals of Cephalanthera damasonium is related to leaf chlorophyll concentrations. New Phytologist, 189(3): 790-796.

Tuzlaci, E. A Dictionary of Turkish Plants, Alfa Publishing, pp: 353, Istanbul (2006).

Vardar Y. 1987. Botanikte preparasyon tekniği. Ege Üniversitesi, Izmir.

Ziegler, C. Favored Flowers: Culture and Economy in a Global System, Duke University Press, USA.(2007) 